\title{
TRANSFORMASI GELOMBANG SOLITER OLEH FLEKSIBILITAS VEGETASI PANTAI
}

\author{
Tri Octaviani Sihombing ${ }^{1}$ \\ Dosen Tetap, Program Studi Teknik Sipil, Universitas Kristen Maranatha \\ Prof. drg. Soeria Sumantri, MPH, No. 65, Bandung, 40164 \\ e-mail: tri.octaviani@maranatha.edu
}

\begin{abstract}
ABSTRAK
Beberapa model vegetasi gelombang disajikan dalam peneitian ini untuk mensimulasikan interaksi gelombang soliter dengan vegetasi fleksibel. CFD berdasarkan model tiga dimensi Navier-Stokes (RANS) Reynolds dengan model turbulen renormalization group (RNG) dikaitkan dengan metode volume of fluid (VOF) diterapkan untuk simulasi numerik. Penelitian ini mencoba untuk memberikan model fisik yang lebih baik dengan mempertimbangkan silinder fleksibel sebagai vegetasi untuk mensimulasikan kinerja redaman vegetasi. Transformasi gelombang dan karakteristik variasi medan alir gelombang soliter yang menyebar di kedua silinder kaku dan silinder fleksibel adalah topik yang akan dibahas. Hasil simulasi numerik menunjukkan bahwa ketika gelombang soliter merambat disekitar vegetasi yang kaku dan fleksibel, energi kinetik turbulen dan laju disipasinya dihasilkan karena interaksi antara gelombang dan silinder. Selanjutnya, hasilnya menunjukkan bahwa vegetasi kaku memperoleh reduksi tinggi gelombang yang lebih besar daripada vegetasi fleksibel. Vegetasi kaku juga mengalami energi kinetik turbulen yang lebih besar daripada yang fleksibel. Hal ini menjadi catatan penting bahwa redaman gelombang mungkin terlalu tinggi ketika mempertimbangkan sekelompok silinder kaku sebagai vegetasi pesisir untuk mensimulasikan dampak vegetasi terhadap redaman tsunami.
\end{abstract}

Kata kunci: Tsunami, Gelombang soliter, Vegetasi fleksibel, FlOW-3D

\begin{abstract}
A coupled wave-vegetation model is presented in this paper for simulating the interaction of solitary waves with the emergent flexible vegetation. A CFD based on the three-dimensional Reynolds-averaged Navier-Stokes (RANS) with renormalization group (RNG) turbulent model associated with volume of fluid (VOF) method was applied for the numerical simulations. This study attempts to provide a better physical model by considering flexible cylinder as the vegetation to simulate damping performance of the vegetation. The wave transformations and the flow field variations characteristics of solitary waves propagating over both rigid cylinders and flexible cylinders are discussed. The numerical simulation results showed that as the solitary wave propagated over the both rigid and flexible vegetation, the turbulent kinetic energy and its dissipation rate are generated due to the interaction between wave and cylinder. Furthermore, the results indicate that the rigid vegetation obtains a greater wave height deduction than the flexible vegetation. Rigid vegetation also experienced more turbulent kinetic energy than the flexible one. This becomes an important note that the wave decay maybe overestimated by considering a group of rigid cylinders as coastal vegetation for the simulation on the effect of vegetation to tsunami damping.
\end{abstract}

Keywords: Tsunami, Solitary wave, Flexible vegetation, FLOW-3D

Transformasi Gelombang Soliter Oleh Fleksibilitas

Vegetasi Pantai (Tri Octaviani Sihombing) 


\section{PENDAHULUAN}

Bencana besar tsunami yang terjadi di Asia Tenggara telah menelan banyak korban dan menyebabkan kerusakan pada Desember 2004. Oleh karena tsunami telah menjadi ancaman yang selalu ada terhadap kehidupan dan properti di sepanjang garis pantai dunia, maka harus dilakukan upaya proaktif dalam mengembangkan cara mengurangi dampak tsunami. Bencana ini telah menimbulkan perdebatan tentang peran yang dimainkan oleh ekosistem pesisir seperti hutan mangrove dan terumbu karang dalam melindungi wilayah pesisir. Baird (2006) telah mencatat bahwa program puluhan juta dolar telah disahkan untuk memulihkan dan melestarikan vegetasi pesisir di 12 negara Asia dan Afrika untuk perlindungan pesisir terhadap tsunami di masa depan.

Untuk alasan tersebut, beberapa penulis telah menunjukkan bahwa hutan mangrove sebagai vegetasi telah memberikan perlindungan pesisir. Energi gelombang tsunami, tinggi dan kecepatan berkurang secara signifikan saat gelombang menyebar melalui hutan mangrove (Harada dan Kawata, 2004; Hiraishi dan Harada, 2003; Harada dan Imamura, 2000; Teh et al., 2009). Namun, Shuto (1987) mencatat bahwa jika ketinggian gelombang melebihi $4 \mathrm{~m}$, pohon bakau mungkin tercerabut; sehingga menciptakan puing-puing yang bisa menyebabkan kerusakan sekunder.

Eksperimen laboratorium atau bahkan kerja lapangan dapat memberikan data berharga, namun sulit dikendalikan, mahal untuk dilakukan dan bahkan tidak mungkin dilakukan untuk meniru. Sebagai alternatif, pendekatan numerik telah dikembangkan untuk memprediksi dan mereproduksi efek hutan mangrove dalam perambatan gelombang tsunami. Dengan menggunakan pendekatan numerik tiga dimensi, Maza et al. (2015) mensimulasikan interaksi gelombang soliter dengan vegetasi yang muncul dan kaku. Baik Maza et al. (2015) dan Huang et al. (2011) dan peneliti lainnya (misalnya, Anderson et al, 2011; Wu et al, 2016), vegetasi mangrove dianggap kaku yang mengabaikan gerak tanaman di bawah tindakan gelombang. Kenyataannya, batang vegetasi dapat bergerak seperti kantilever atau cambuk yang didorong oleh gelombang (Paul et al, 2012) karena vegetasi alami dapat berubah bentuk, yang mengurangi hambatan aliran.

Untuk memberikan pemodelan yang lebih baik, makalah ini mempertimbangkan vegetasi dengan menggunakan sekelompok silinder fleksibel, daripada menggunakan silinder kaku. Dalam penelitian ini, computational fluid dynamics (CFD) multi-fisika yang sangat kuat dan sangat akurat, FLOW-3D, digunakan untuk pendekatan simulasi gelombang tsunami yang berinteraksi dengan silinder fleksibel. Transformasi gelombang 
dan karakteristik variasi medan alir gelombang soliter yang merambat di atas kedua silinder kaku dan silinder fleksibel, masing-masing, dibahas dalam makalah ini.

\section{MODEL NUMERIK}

Simulasi numerik ini dibuat dengan menggunakan persamaan Reynolds-averaged Navier-Stokes (RANS)) dengan model turbulen renormalization group (RNG) $k$ - $\varepsilon$. Untuk memodelkan batas geometris kompleks dengan teknik pecahan representasi sudut/ volume (FAVOR) (Hirt dan Sicilian, 1985), persamaan kontinuitas dan momentum umum untuk arus turbulen yang masif diformulasikan dengan fungsi fraksi area dan volume, yang diberikan sebagai berikut,

$$
\begin{gathered}
\frac{\partial\left\langle u_{i}\right\rangle A_{i}}{\partial x_{i}}=0 \\
\frac{\partial\left\langle u_{i}\right\rangle}{\partial t}+\frac{1}{V_{F}}\left\langle U_{j}\right\rangle A_{j} \frac{\partial\left\langle u_{i}\right\rangle}{\partial x_{i}}=-\frac{1}{\rho} \frac{\partial\langle p\rangle}{\partial x_{i}}+\frac{1}{\rho V_{F}} \frac{\partial}{\partial x_{j}}\left[A_{j}\left(\left\langle\tau_{i j}\right\rangle+R_{i j}\right)\right]
\end{gathered}
$$

dimana $\tau_{i j}=2 \mu S_{i j}$ dengan $S_{i j}=\left(\partial\left\langle u_{i}\right\rangle / \partial x_{j}+\partial\left\langle u_{j}\right\rangle / \partial x_{i}\right) / 2$ dengan notasi \langle\rangle menunjukkan ansambel-rata-rata, $u$ adalah komponen kecepatan dalam arah subskrip $=1$, 2 mewakili arah $x$ - dan $z$-, berurutan, $p$ adalah intensitas tekanan, $\rho$ adalah kerapatan fluida, $g$ adalah percepatan gravitasi, dan $\mu$ adalah viskositas absolut. $V_{F}$ adalah volume pecahan terbuka terhadap arus dan $A$ adalah untuk arah subscript yang baik $V_{F}$ dan $A$ di set menjadi satu. Tegangan Reynolds $R_{i j}$ pada Pers. (2) dituliskan dengan:

$$
R_{i j}=2 \rho v_{t} S_{i j}-\frac{2}{3} \rho k \delta_{i j}
$$

dimana $v_{t}$ adalah Eddy viskositas, $k$ adalah energi kinetic turbulen, dan $\delta_{i j}$ adalah fungsi Kronecker delta seperti $\delta_{i j}=1$ ketika $i=j ; \delta_{i j}=0$, dan $i \neq j$. Pada Pers. (3), visikositas Eddy $v_{t}$ terkait dengan efek ruang dan distribusi waktu gerak turbulen, yang diselesaikan menggunakan metode renormalization group (RNG $k-\varepsilon$ model). Yokhot dan Orszag (1986) mengusulkan model turbulen RNG $k-\varepsilon$ dan membuat perbaikan atas model $k-\varepsilon$.

Solusi numerik diimplementasikan dalam aplikasi Flow-3D CFD (Flow Science, 2012), memanfaatkan metode volume of fluid (VOF) (Hirt and Nichols, 1981) untuk secara akurat menghitung permukaan air bebas dan model efisien geometri padat menggunakan yang teknik FAVOR. Beberapa penelitian telah menerapkan Flow-3D Transformasi Gelombang Soliter Oleh Fleksibilitas 
untuk mensimulasikan interaksi gelombang dan struktur, mislanya Choi et al. (2007) dan Dentale et al. (2014). Pada studi numerik kali ini, solusi dari gelombang soliter yang berasal dari persamaan Boussinesq digunakan sebagai gelombang peristiwa, yang dinyatakan sebagai:

$$
\eta(x, t)=H \operatorname{sech}^{2}\left\lfloor\sqrt{\frac{3 H}{4 h_{0}^{3}}(x-c t)}\right\rfloor
$$

dimana $\eta$ adalah elevasi permukaan bebas, $h_{0}$ adalah kedalaman muka air tetap, $H$ tinggi gelombang, dan $c$ adalah gelombang celerity $\left(c=\sqrt{g\left(h_{0}+H\right)}\right)$.

\section{VALIDASI}

Hasil laboratorium yang dilakukan oleh Huang et al. (2011) digunakan untuk melakukan validasi akurasi hasil dari model numerik yang akan disimulasikan. Simulasi ini dilakukan dengan menggunakan geometri gelombang saluran yang sama, kedalaman air dan karakteristik gelombang soliter seperti Huang et al. (2011). Semua tes digridnkan dalam saluran dengan panjang $32 \mathrm{~m}$ dan lebar $0,55 \mathrm{~m}$, kedalaman air sama dengan $\mathrm{h}=$ $0,15 \mathrm{~m}$, menggunakan silinder dengan diameter $0,01 \mathrm{~m}$ yang muncul dengan susunan $\mathrm{C}$ dengan kerapatan sama dengan $\mathrm{N}=560$ silinder $/ \mathrm{m}^{2}$ dan panjang bidang $1,635 \mathrm{~m}$. Untuk mengatasi error komputasi dan memberikan akurasi hasil, ukuran mesh 0,005m di sepanjang semua domain dipilih. Kondisi batas adalah gelombang soliter sebagai $\mathrm{x}$ minimum, outflow sebagai x maksimum, dan simetri pada y minimum dan $\mathrm{m}$, lalu digunakan dinding sebagai z minimum dan maksimum. Lokasi pengukur dan aturan grid (mesh) dapat dilihat pada Gambar 1. Tinggi gelombang relatif dari gelombang soliter, $\mathrm{H}$ / h, sama dengan 0,33 .

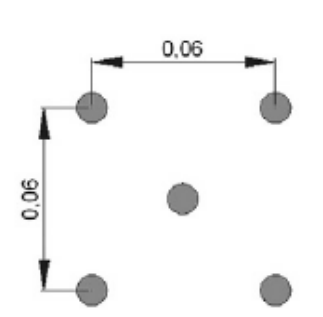

(a)

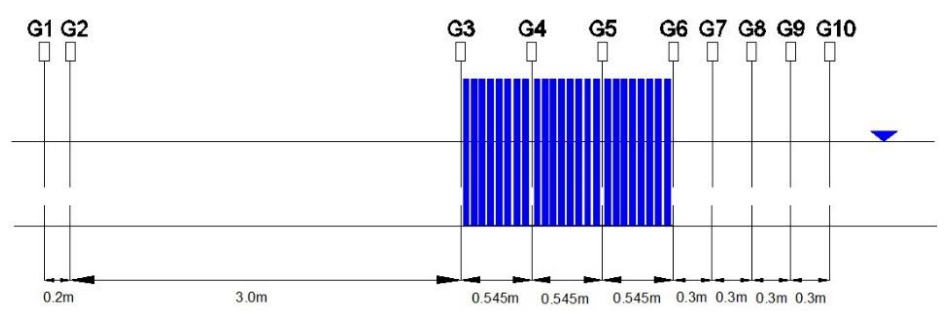

(b)

(c)

Gambar 1: (a) Pengaturan silinder, (b) Lebar bidang dan posisi alat ukur dan (c) Kondisi grid (mesh) 

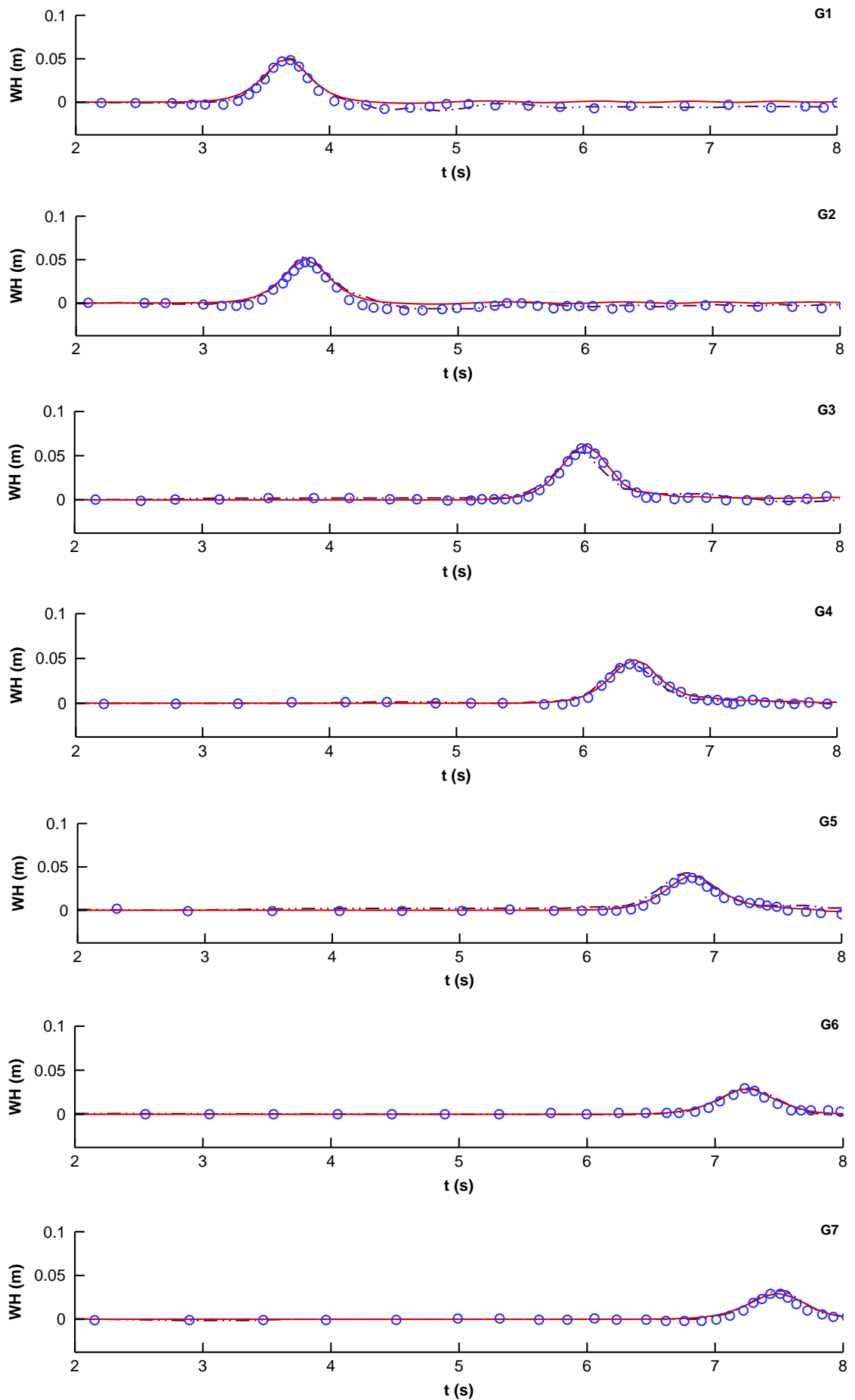

Gambar 2: Perbandingan transformasi gelombang antara studi numerik saat ini (garis merah) dan hasil eksperimen oleh Huang et al. (garis bulat biru), dan juga hasil numerik oleh Maza et al. (garis putus-putus coklat) untuk $H / h=0.33$

Gambar 2 menunjukkan perbandingan antara hasil numerik saadan eksperimen oleh Huang et al. (2011). Hasil numerik oleh Maza et al. (2015) juga dibandingkan. Root 
mean square error (RMSE) digunakan untuk mengukur, yang didefinisikan melalui pers. (7) diman $y_{i}$ adalah nilai numerik, $y_{i}^{t}$ adalah nilai dan $\mathrm{n}$ adalah total data.

$$
\text { RMSE }=\sqrt{\frac{1}{n} \sum_{0}^{n}\left(y_{i}-y_{i}{ }^{\prime}\right)^{2}}
$$

Baik gambar 2 dan gambar 3 menunjukkan bahwa hasil numerik saat ini sesuai dengan hasil terukur.

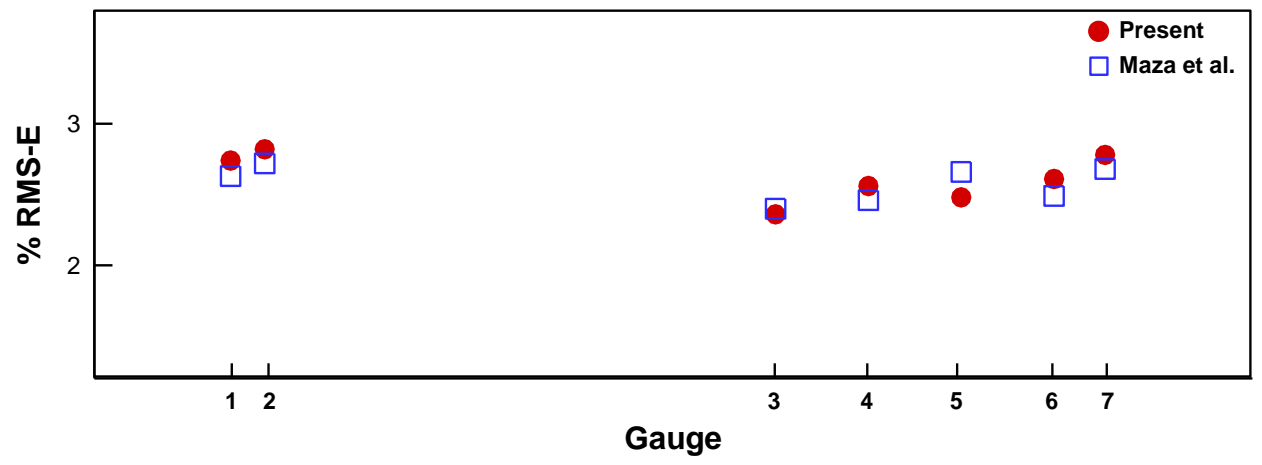

Gambar 3: RMS Error antara studi numerik saat ini (present) dengan hasil eksperimen (bulatan merah), dan studi numerik oleh Maza et al. dengan hasil eksperimen (persegi biru)

\section{HASIL DAN DISKUSI}

Setelah melakukan validasi terhadap Huang et al. (2011) dan konfirmasi dengan Maza et al. (2015), pengaruh dari tinggi gelombang relatif pada pengurangan tinggi gelombang akan dianalisa terlebih dulu. Tiga tinggi gelombang soliter dipilih $(0.05 \mathrm{~m}$, $0.04 \mathrm{~m}$, and $0.025 \mathrm{~m}$ ) untuk disimulasikan dengan mempertimbangkan pengaturan $\mathrm{C}$ terhadap silinder kaku, tinggi gelombang relatif $(H / h)$ adalah $0.33,0.27,0.17$.

Silinder diletakkan pada lokasi antara alat ukur (gauge) G3 dan G6, seperti pada gambar 4, maka dapat dilihat bahwa fenomena pengurangan tinggi gelombang terlihat signifikan pada daerah tersebut.

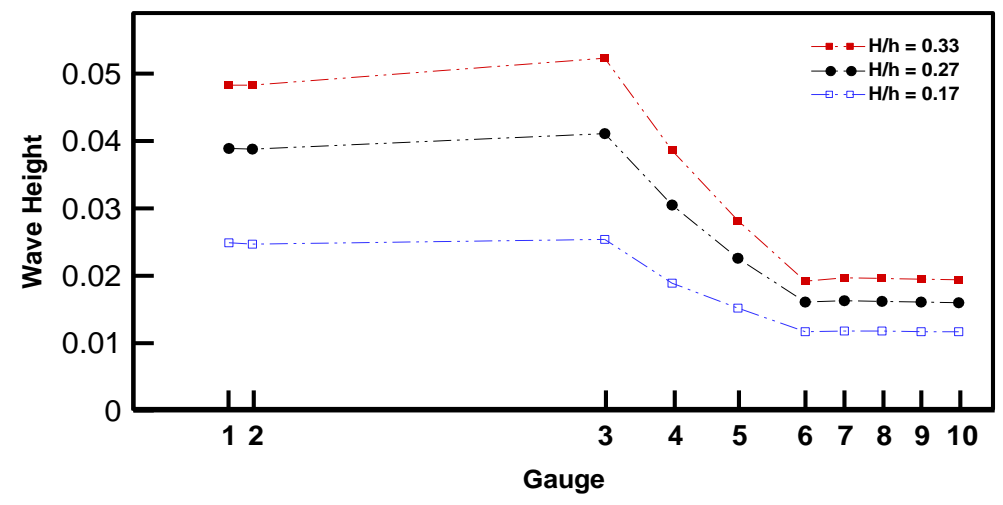

Gambar 4: Tinggi gelombang variasi untuk silinder kaku 
Untuk mengevaluasi redaman gelombang oleh silinder, energi turbulen kinetik (turbulent kinetic energy, TKE) dan tingkat dissipasi energi turbulen kinetik (turbulent kinetic energy dissipation rate, DTKE) diperhitungkan. Gambar 5 menunjukkan nilai TKE dan DTKE di setiap lokasi saat puncak gelombang soliter melewatinya. Bisa diamati bahwa TKE maksimum dihasilkan pada G4 dan DTKE maksimum dihasilkan pada G5. Mengenai pengaruh tinggi gelombang relatif, dapat dilihat bahwa tinggi gelombang yang lebih tinggi menghasilkan TKE dan DTKE yang lebih besar pula.
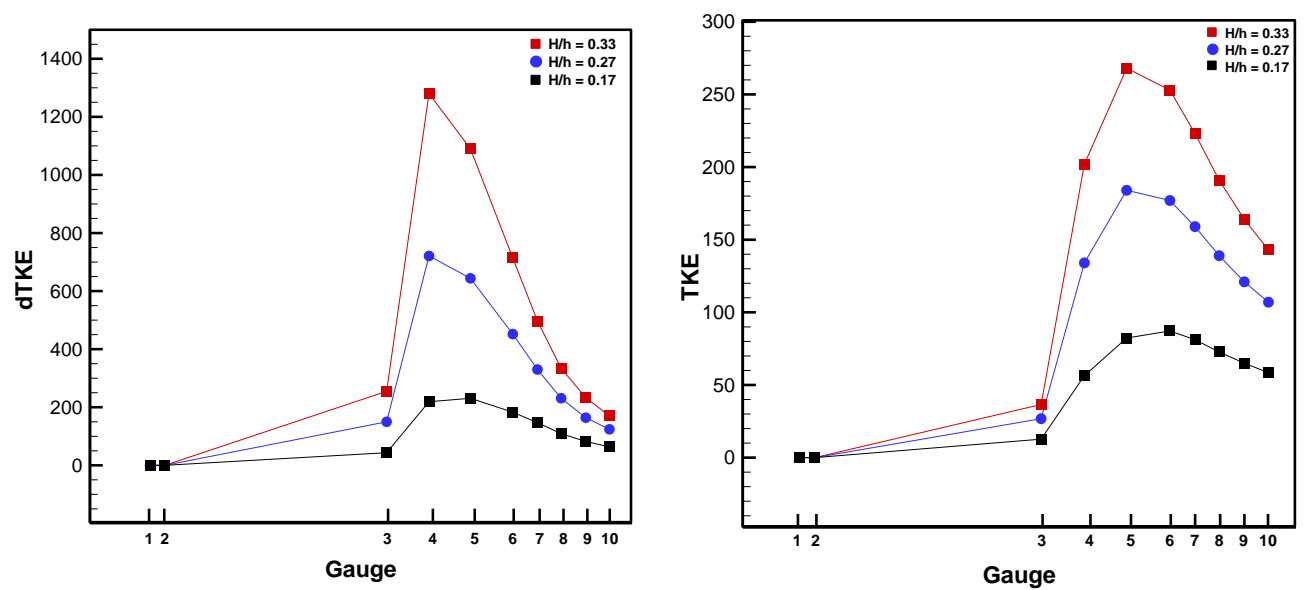

Gambar 5: Energi kinetik turbulen dan laju didipasi energi kinetik turbulen pada silinder kaku untuk 3 tinggi gelombang yang berbeda.

Karena tujuan dari penelitian ini adalah untuk memberikan model fisik yang lebih baik, kasus silinder fleksibel disimulasikan dengan kondisi gelombang yang sama seperti kasus silinder kaku. Dengan menggunakan fungsi General Moving Object (GMO) pada silinder kaku di bawah semua jenis gerak fisik yang digabungkan secara dinamis dengan aliran fluida, bagian simulasi ini membuat pengaturan silinder dapat bergerak dengan $\mathrm{x}$ derajat kebebasan (DOF). Model GMO ini bekerja baik dalam sistem koordinat Cartesian dan silinder FLOW-3D. Untuk membandingkan peredaman gelombang dengan silinder fleksibel yang muncul dan silinder kaku, tinggi gelombang relatif $\mathrm{H} / \mathrm{h}=0,33$ akan dibahas.

Distribusi medan kecepatan berdasarkan variasi waktu elevasi permukaan pada setiap lokasi pengukur ditunjukkan pada Gambar 6 untuk perambatan gelombang di atas silinder kaku dan silinder fleksibel. Gambar 7 menunjukkan bahwa silinder kaku terlihat bekerja lebih baik daripada silinder fleksibel untuk mengurangi tinggi gelombang.

Sebelum gelombang soliter mencapai struktur, transformasi gelombang antara silinder yang kaku dan fleksibel tidak banyak perbedaan. Namun fenomena yang berbeda 
muncul dari G4 ketika dan setelah rambatan gelombang berada di atas struktur seperti ditunjukkan pada Gambar 8, tinggi gelombang meluruh lebih banyak oleh silinder kaku. Ada rasio redaman tinggi gelombang sebesar $43,5 \%$ untuk silinder yang kaku sedangkan pada silinder fleksibel hanya 16,3\% pada G5. Setelah gelombang melewati silinder, rasio redaman tinggi gelombang untuk silinder fleksibel sekitar $25 \%$ tetapi sekitar $60 \%$ untuk silinder kaku.

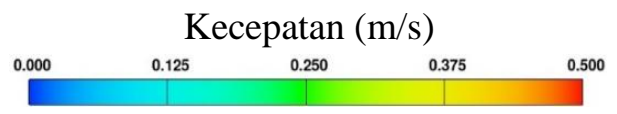

Silinder fleksibel

Silinder kaku

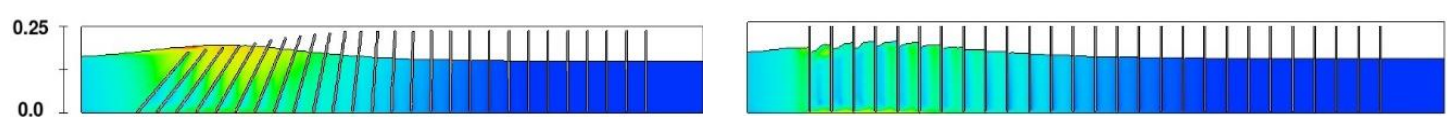

(a) $t=4 s$

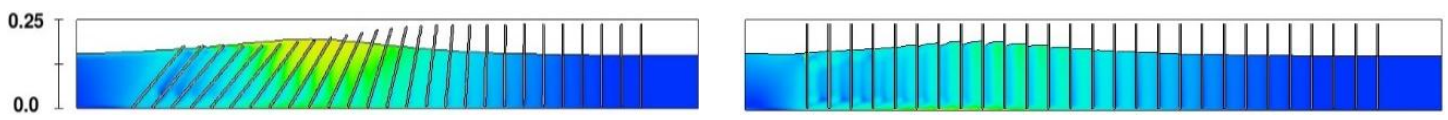

(b) $\mathrm{t}=4.2 \mathrm{~s}$

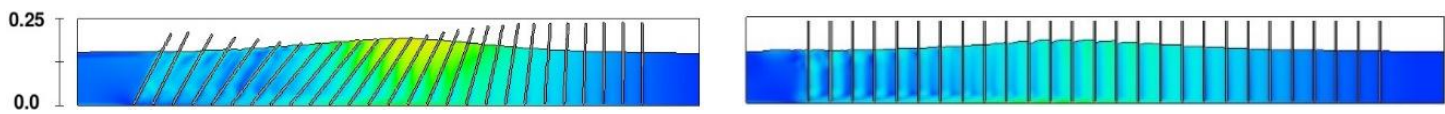

(c) $\mathrm{t}=4.4 \mathrm{~s}$

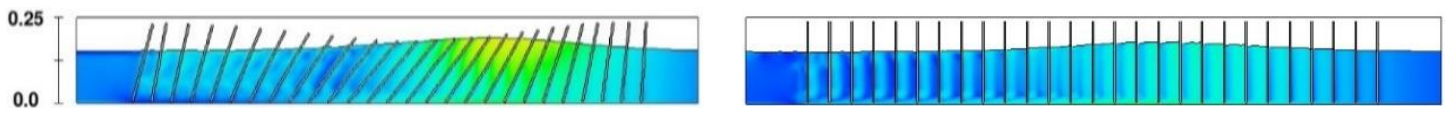

(d) $\mathrm{t}=4.6 \mathrm{~s}$

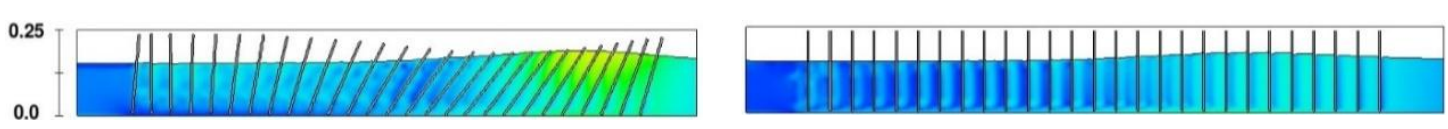

(e) $\mathrm{t}=4.8 \mathrm{~s}$
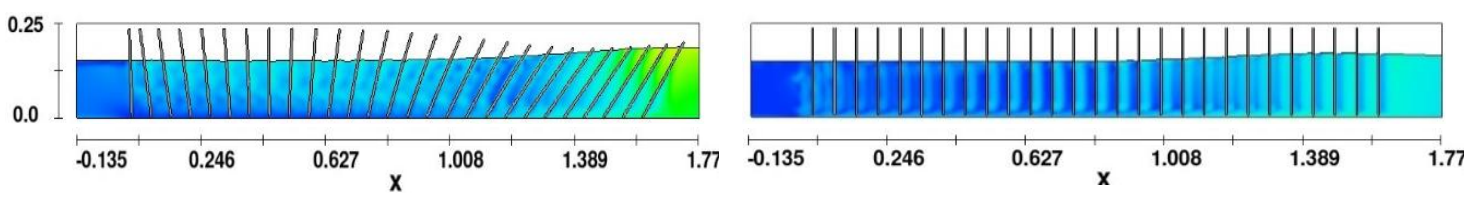

(f) $t=5 s$

Gambar 6: Distribusi medan kecepatan antara silinder yang kaku dan fleksibel 

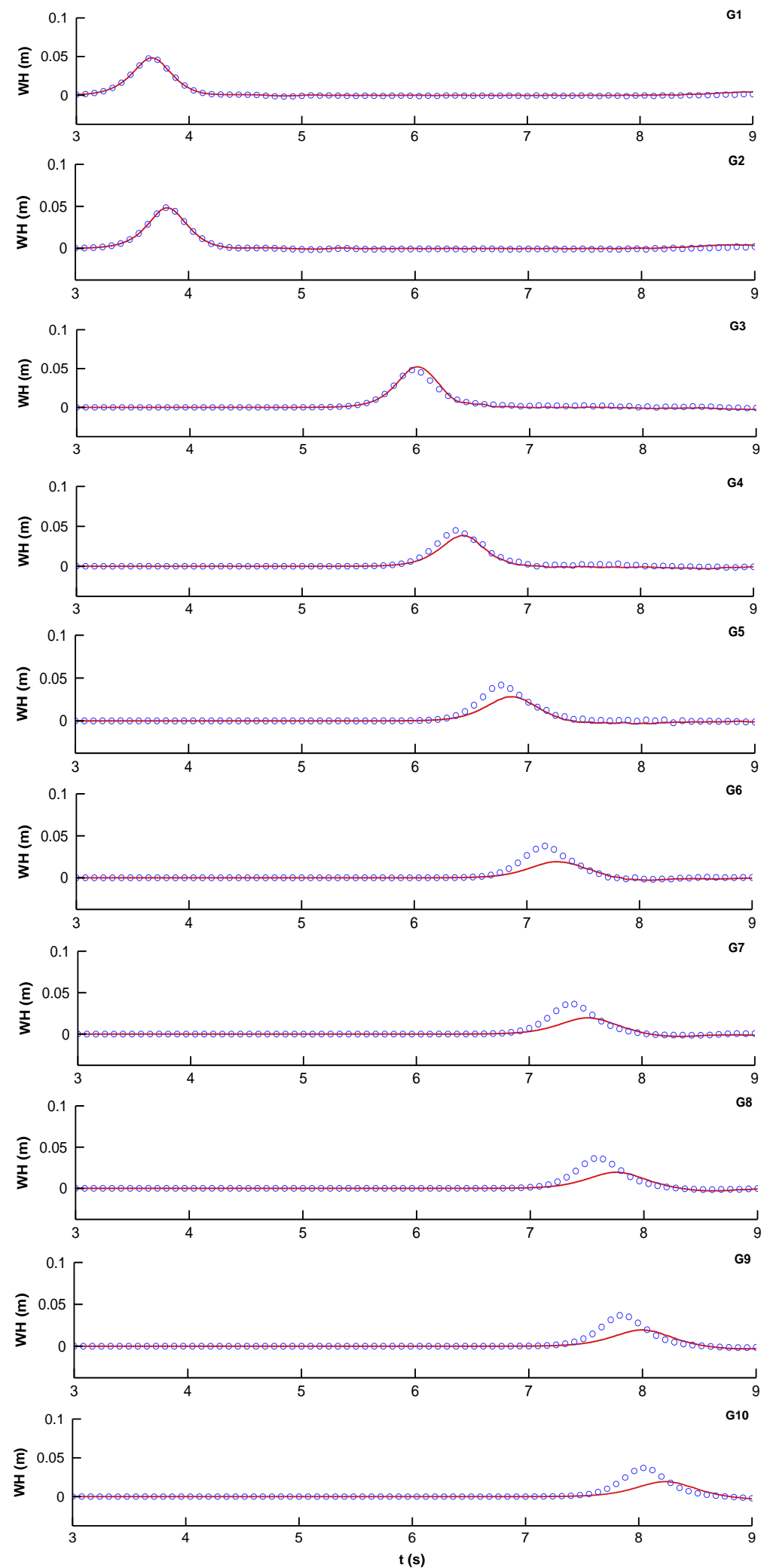

Gambar 7: Perbandingan transformasi tinggi gelombang antara silinder kaku (garis merah) dan silinder fleksibel (garis bulat biru) 


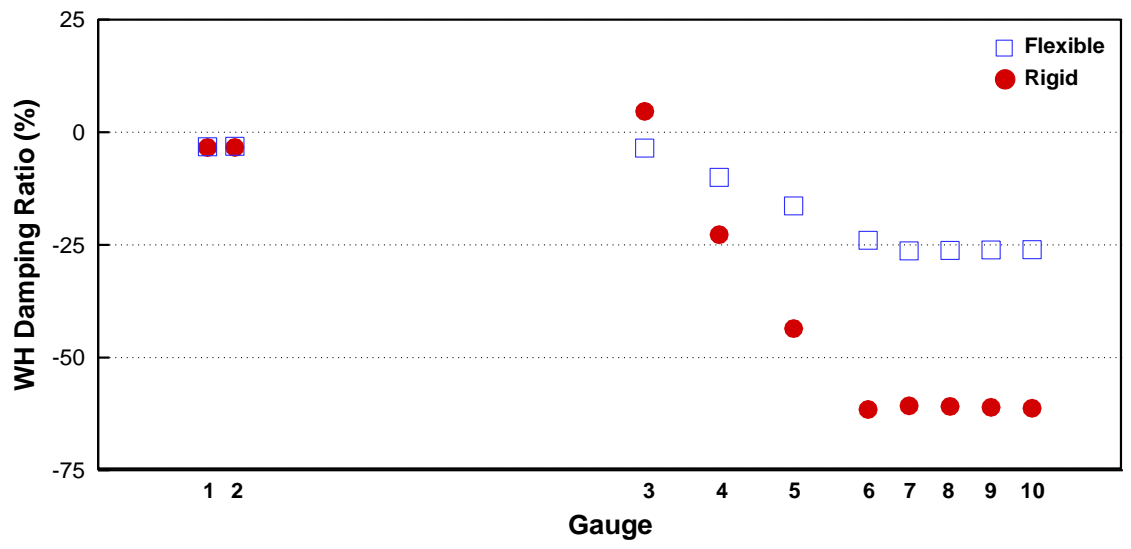

Gambar 8: Perbandingan redaman tinggi gelombang antara silinder kaku (bulatan merah) dan silinder fleksibel (persegi biru) di setiap alat pengukur (gauge).

Gambar 9 (b) menunjukkan medan alir saat puncak gelombang melewati alat pengukur 5. Dapat diamati bahwa silinder fleksibel berputar maju mengikuti gerakan gelombang. Tapi, secara simultan, silinder yang berada diantara G3 dan G4 lebih kuat terayun kembali ke belakang saat gelombang melewatinya.

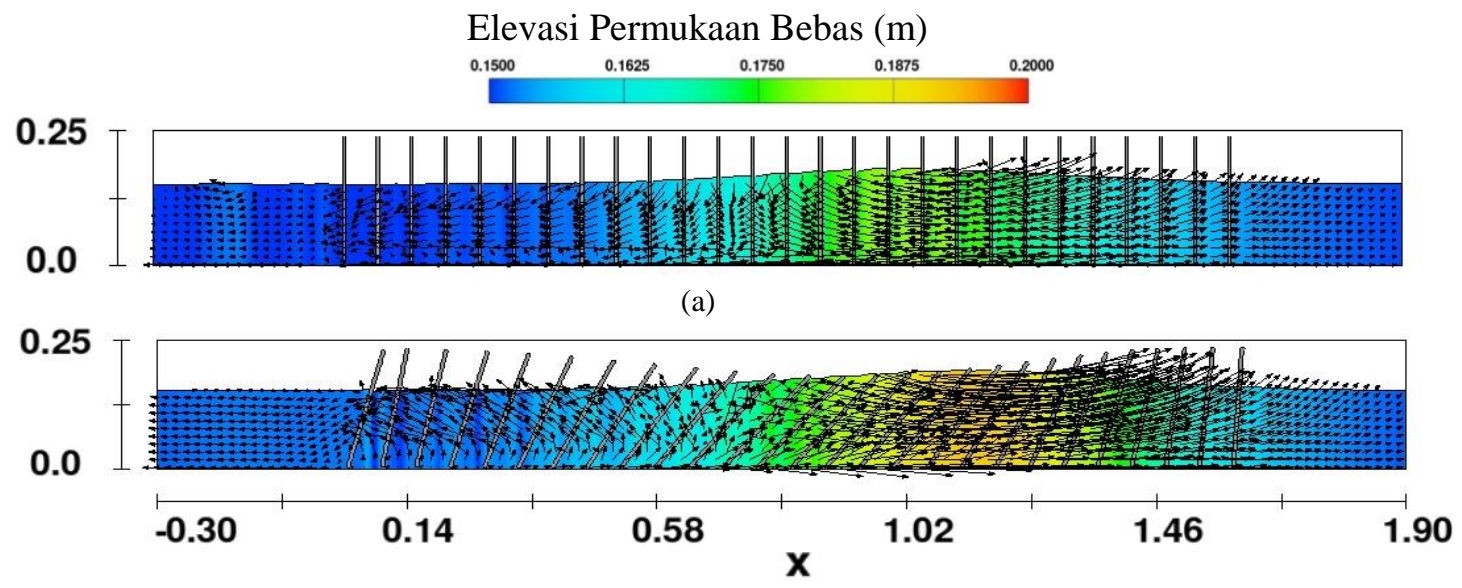

(b)

Gambar 9: Bidang arus berdasarkan perambatan gelombang melalui G5 untuk (a) silinder kaku dan (b) silinder fleksibel.

Gambar 10 dan Gambar 11 menunjukkan variasi waktu dari energi kinetik turbulen (TKE) dan laju disipasi energi kinetik turbulen (DTKE) dari silinder kaku dan silinder fleksibel. Hasilnya menunjukkan bahwa silinder kaku mengalami energi kinetik turbulen lebih besar daripada silinder fleksibel. Dengan meningkatnya kekakuan vegetasi, disipasi energi turbulen terjadi di daerah yang relatif luas. Juga menarik untuk dicatat bahwa waktu terjadinya TKE maksimum atau bahkan DTKE maksimum dalam silinder fleksibel berbeda dengan silinder kaku. TKE dan DTKE maksimum pada silinder fleksibel ditemukan pada 4,4 s dan 4,6 s saat silinder bergerak mundur setelah gelombang. 


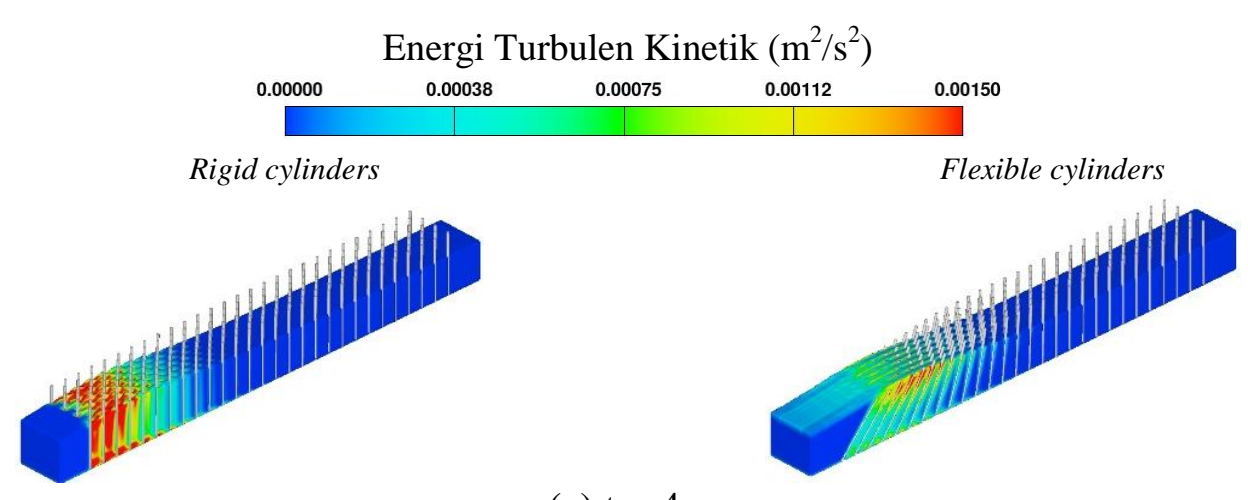

(a) $t=4 s$
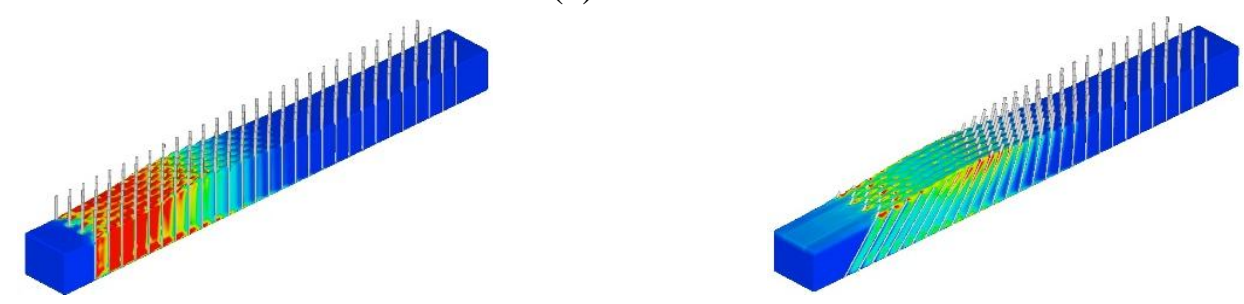

(b) $t=4.2 s$
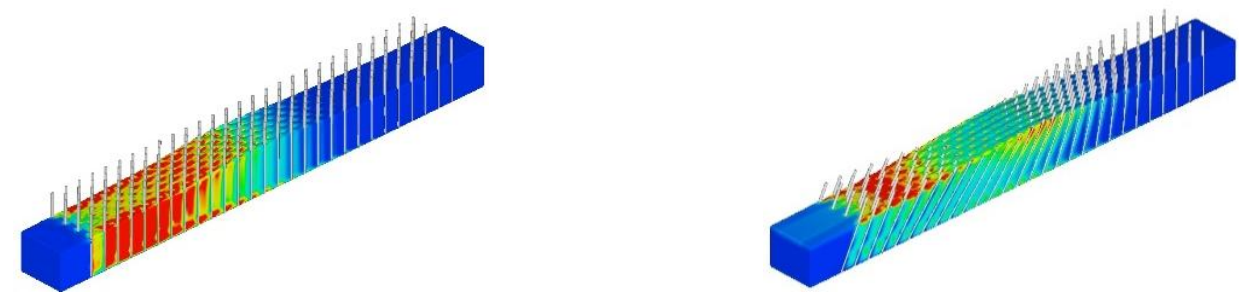

(c) $\mathrm{t}=4.4 \mathrm{~s}$
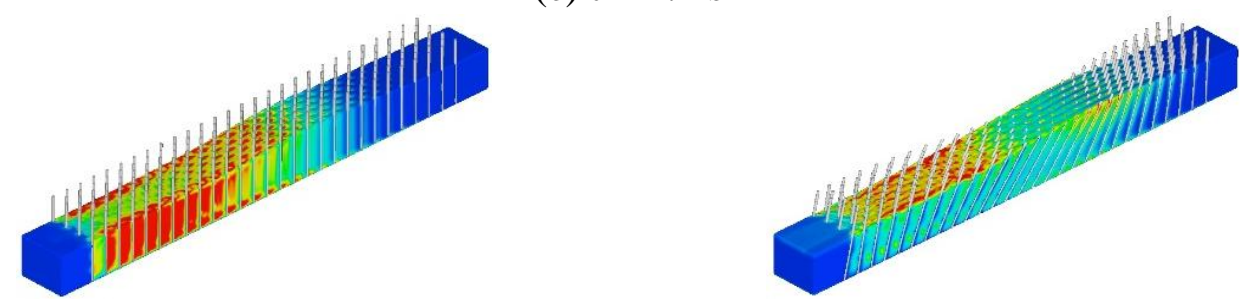

(d) $t=4.6 \mathrm{~s}$
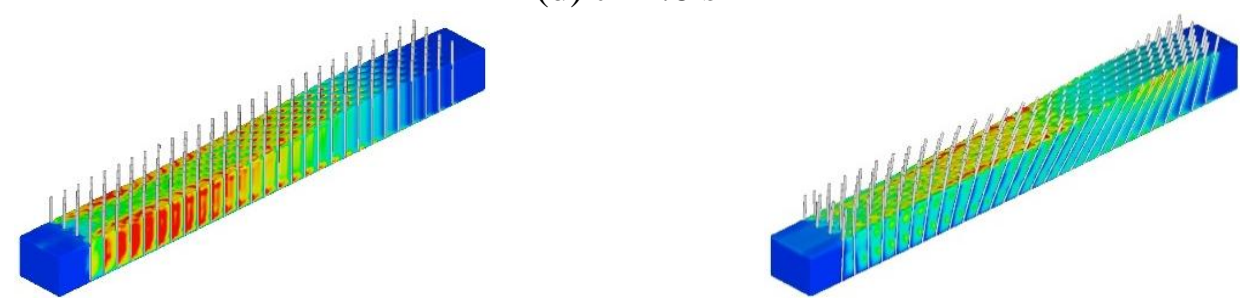

(e) $\mathrm{t}=4.8 \mathrm{~s}$
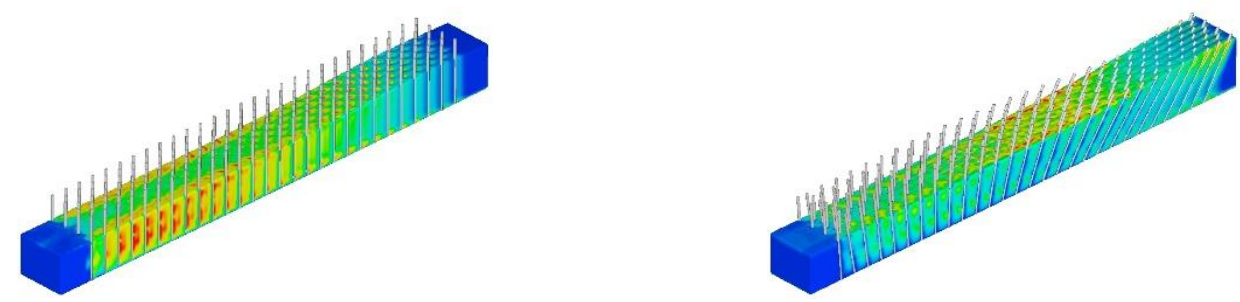

(f) $\mathrm{t}=5 \mathrm{~s}$

Gambar 10: Energi turbulen kinetik untuk silinder kaku dan fleksibel.

Transformasi Gelombang Soliter Oleh Fleksibilitas 

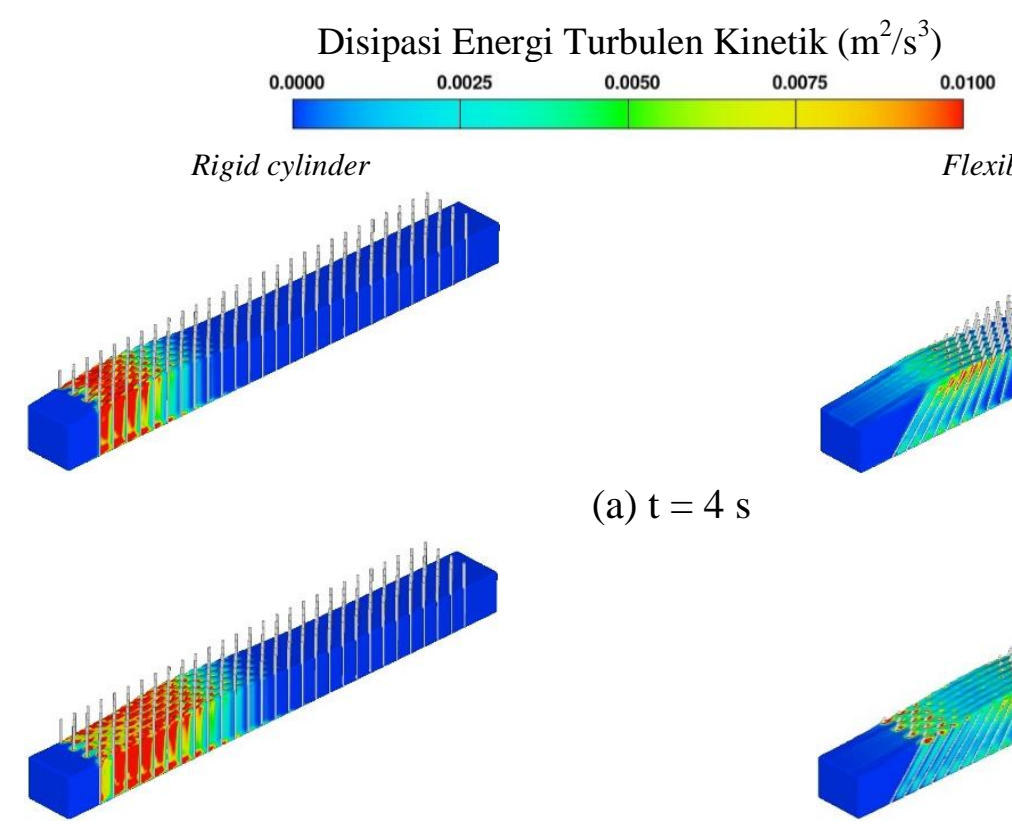

(a) $t=4 s$
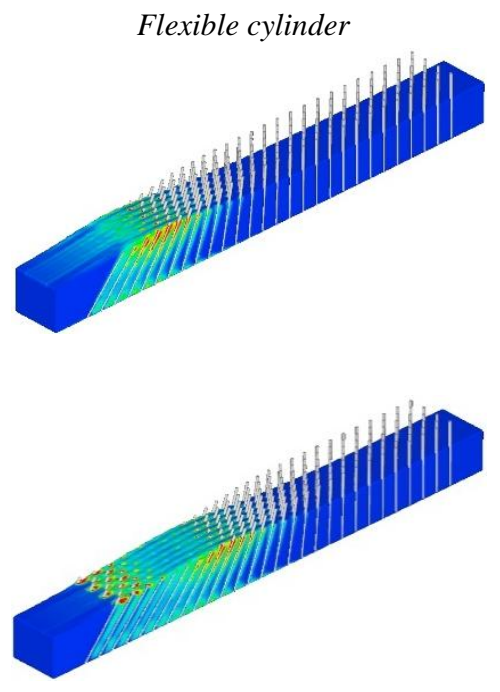

(b) $\mathrm{t}=4.2 \mathrm{~s}$
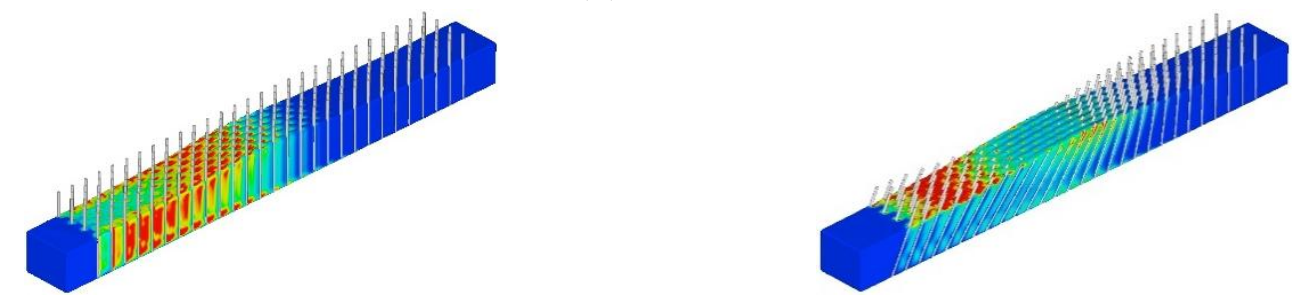

(c) $\mathrm{t}=4.4 \mathrm{~s}$
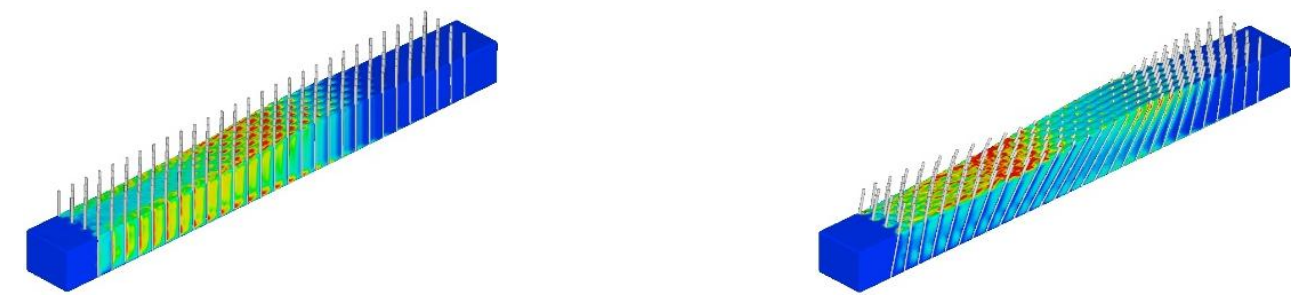

(d) $\mathrm{t}=4.6 \mathrm{~s}$
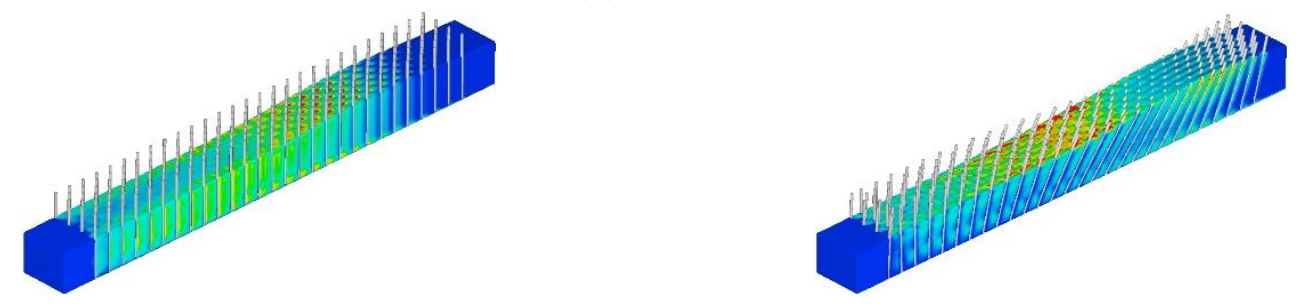

(e) $\mathrm{t}=4.8 \mathrm{~s}$
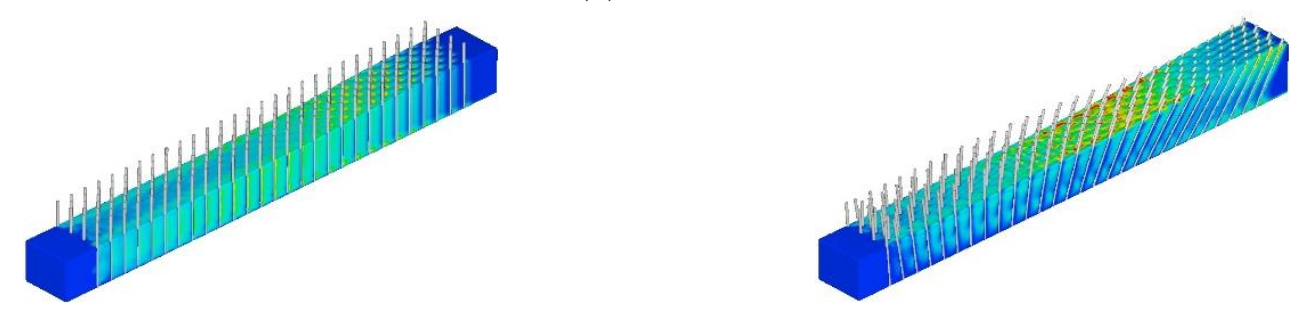

(f) $\mathrm{t}=5 \mathrm{~s}$

Gambar 11: Disipasi energi turbulen kinetik untuk silinder kaku dan fleksibel. 


\section{SIMPULAN}

Pendekatan numerik tiga dimensi berdasarkan model RANS digunakan untuk mempelajari interaksi gelombang tsunami dengan vegetasi. Transformasi tinggi gelombang, medan aliran dan energi kinetik turbulen dan laju disipasi gelombang soliter yang menyebar di atas silinder yang kaku dan fleksibel menjadi topik yang diselidiki dalam penelitian ini. Hasil simulasi numerik menunjukkan bahwa setelah gelombang soliter disebarkan di atas vegetasi yang kaku dan fleksibel, energi kinetik turbulen dan laju disipasi dihasilkan karena interaksi antara gelombang dan silinder. Hasilnya menunjukkan bahwa vegetasi yang kaku memiliki redaman tinggi gelombang yang lebih besar daripada yang fleksibel. Vegetasi kaku juga mengalami energi kinetik turbulen yang lebih besar daripada yang fleksibel, yang berarti mengurangi lebih banyak energi setelah gelombang melewati vegetasi. Padahal, struktur vegetasi pesisir jauh dari makna fisik yang kaku seperti yang digunakan oleh beberapa penelitian terdahulu. Hal ini menjadi catatan penting bahwa kemungkinan overestimasi terhadap peluruhan gelombang ketika menggunakan silinder kaku sebagai vegetasi pesisir perlu dipertimbangkan kembali untuk upaya pencegahan bencana apapun.

\section{REFERENSI}

1. Anderson, M. E., Smith, J. M., and McKay, S. K., 2011. Wave dissipation by vegetation. Coastal and Hydraulics Engineering Technical Note ERDC/CHL CHETN-I-82, U.S. Army Engineer Research and Development Center, Vicksburg, MS.

2. Baird, A.H., 2006. Myth of green belts. Viewpoint, SAMUDRA Report No. 44.

3. Chen, X., Chen, Q., Zhan, J., Liu, D, 2016. Numerical simulations of wave propagation over a vegetated platform. Coast. Eng., 110, 64-75.

4. Choi, B.H., D.C. Kim, E. Pelinovsky and S.B. Woo, 2007. Three-dimensional simulation of tsunami run-up around conical island. Coastal Engineering 54, 618-629.

5. Cooker, M. J., D.H. Peregrine, C. Vidal and J.W. Dold, 1990. The interaction between a solitary wave and a submerged semicircular cylinder. Journal of Fluid Mechanics 215, 1-22.

6. Dentale, F., G. Donnarumma and E. Pugliese Carratelli, 2014. Simulation of flow within armour blocks in a breakwater. Journal of Coastal Research 30(3), 528-536. 
7. Harada, K. and Imamura, F., 2000. Experimental study on the resistance by mangrove under the unsteady flow, $1^{\text {st }}$ Congress of the Asian and Pacific Coast. Eng., 975-984.

8. Harada, K. and Kawata, Y., 2004. Study on the effect of coastal forest to tsunami reduction. Annuals of Disas. Prev. Res. Inst., Kyoto Univ., No. 47 C.

9. Hiraishi, T., Harada, K., 2003. Greenbelt tsunami prevention in south-Pacific region. Report of the Port and Airport Research Institute 42 (2), 3-25.

10. Hirt, C.W. and B.D. Nichols, 1981. Volume of fluid (VOF) method for dynamics of free boundaries. Journal of Computational Physics 39, 201-225.

11. Huang, Z., Yao, Y., Sim, S. Y., and Yao, Y., 2011. Interaction of solitary waves with emergent rigid vegetation, Ocean Eng., 38, 1080-1088.

12. Li, C.W., Xie, J.F., 2011. Numerical modeling of free surface flow over submerged and highly flexible vegetation. Adv. in Water Resources, 34, 468-477.

13. Liu, P.L.F., H. Yeh, and C.E. Synolakis. 2008. Advanced Numerical Models for Simulating Tsunami Waves and Runup, In: Advances in Coastal and Ocean Engineering, World Scientific Pub. (10), Singapore.

14. Maza, Maria, Lara J.L., Losada I.J., 2015. Tsunami wave interaction with mangrove forests: a 3-d numerical approach. Coast. Eng., 98, 33-54.

15. Paul, M., Bouma, T. J., and Amos, C. L. (2012). "Wave attenuation by submerged vegetation: Combining the effect of organism traits and tidal current." Mar. Ecol.

16. Shuto, N., 1987. The effectiveness and limit of tsunami control forests. Coastal Eng in Japan 30, 143-153.

17. Tadepalli, S. and C.E. Synolakis (1994). The Run-Up of N-Waves on Sloping Beaches, Proceedings: Mathematical and Physical Sciences 445(1923), 99-112.

18. Teh, S.Y., Koh, H.L., Liu, P.L.F., Ismail, A.I.M., Lee, H.L., 2009. Analytical and numerical simulation of tsunami mitigation by mangroves in Penang, Malaysia. J. Asian Earth, Sci. 36, 38-46.

19. Wu, W.-C., Ma G., Cox, D.T., 2016. Modeling wave attenuation induced by the vertical density variations of vegetation. Coastal Eng., 112, 17-27.

20. Zhu, L., Chen, Q., 2015. Numerical modeling of surface waves over submerged flexible vegetation. J. Eng. Mech., 141(8). 